\title{
Influence of morphine-induced sensitization on histamine-induced anxiety like behaviors in the elevated plus-maze test Parvin Khodarahmi ${ }^{* 1,2}$, Shahrbanoo Oryan ${ }^{1}$, Mohammad-Reza Zarrindast ${ }^{3}$ and Ameneh Rezayof ${ }^{4}$
}

Address: ${ }^{1}$ Department of Biology, Science and Research Brach, Islamic Azad University, Tehran, Iran, ${ }^{2}$ Department of Biology, Parand Branch, Azad Islamic University, Tehran, Iran, ${ }^{3}$ Department of Pharmacology, Tehran University of Medical Sciences, Tehran, Iran and ${ }^{4}$ School of Biology, University College of Science, University of Tehran, Tehran, Iran

* Corresponding author

from International Society on Brain and Behaviour: 3rd International Congress on Brain and Behaviour Thessaloniki, Greece. 28 November - 2 December 2007

Published: 17 April 2008

Annals of General Psychiatry 2008, 7(SuppI I):S306 doi:10.1 186/I744-859X-7-SI-S306

This abstract is available from: http://www.annals-general-psychiatry.com/content/7/SI/S306

(c) 2008 Khodarahmi et al.; licensee BioMed Central Ltd.

\section{Background}

It has been suggested that histamine have modulatory influence on anxiety-related behaviors both in animals and humans. On the other hand, ventral hippocampus (VHC) may be an important brain site in the modulation of fear or anxiety. In the present study, the effects of bilateral intra-VHC injections of histamine on anxiety-related behavior have been investigated in morphine-sensitized and naive rats using a plus-maze model.

\section{Materials and methods}

Rats, weighing 200-250 gr at the time of surgery, were bilaterally cannulated in the VHC by a stereotaxic instrument, and were allowed to recover 5 days before sensitization. Sensitization was obtained by subcutaneous injections of morphine $(7.5 \mathrm{mg} / \mathrm{kg})$ once daily for 3 consecutive days and then 5 days free of the opioid before test. On the test day, eight rats in each group received bilateral intra-VHC injection of histamine at doses 2.5, 5 and $7.5 \mu \mathrm{g} / \mathrm{rat}$ five minutes before undergoing an elevated plus-maze test.

\section{Results}

A two-way analysis of variances (ANOVA) test between the response of bilateral intra-VHC injection of histamine $(2.5,5$ and $7.5 \mu \mathrm{g} / \mathrm{rat})$ in naive and morphine-sensitized rats using post hoc analysis showed that morphine sensitization increased \%OAT (Open Arm Times) and \%OAE
(Open Arm Entries) indicating an anxiolytic response by morphine sensitization in the presence of histamine.

\section{Conclusions}

Our results indicated that while histamine in naive rats induces anxiogenic response, this behavior was attenuated in morphine sensitized rats.

\section{References}

I. Rostami P, Hajizadeh-Moghaddam A, Zarrindast MR: The effects of histaminergic agents in the ventral hippocampus of rats in the plus-maze test of anxiety-like behaviours. Physiol Behav 2006, 87:89I-6.

2. Zarrindast MR, Rostami P, Zarei M, Roohbakhsh A: Intracerebroventricular effects of histaminergic agents on morghineinduced anxiolysis in the elevated plus-maze in rats. Basic Clin Pharmacol Toxicol 2005, 97:276-8I.

3. Zarrindast MR, Rezayof A: Morphine state-dependent learning: sensitization and interactions with dopamine receptors. Eur J Pharmacol 2004, 497: 197-204.

4. Zarrindast MR, Khalilzadeh A, Malekmohammadia N, Fazli-Tabaei S: Influence of morphine- or apomorphine-induced sensitization on histamine state-dependent learning in the step-down passive avoidance test. Behav Brain Res 2006, I 7 1:50-5. 